\title{
Study on the Policy Evolution and the Practical Significances of the Development of Private Higher Education in China under Classified Management
}

\author{
Zhang Yan \\ Qi Fang Education Research Institute, Xi’an International University, Xi’an Shaanxi 710077
}

Keywords: Private Education Promotion Law; non-profit; private colleges and universities

\begin{abstract}
Educational laws and policies are the keystone and guarantee for the survival and development of private colleges and universities. In China, the classified management for the private colleges and universities is the most important breakthrough of the new revised Private Education Promotion Law. The essence of the classified management, which consists of the new revised law and the relevant documents, is the legislative authority of supporting the non-profit private colleges and universities favorably.
\end{abstract}

As the recent forty-year development of the private higher education in China, many experiences prove a conclusion many times---- educational laws and policies are the keystone and guarantee for the survival and development of private colleges and universities. Without the strong guidance and supports of the correct educational laws and policies, the development of private colleges and universities must be difficult, tortuous and bumpy. Up to now, although private higher education in China has made remarkable achievements, but in general, the social foundation for its survival is still weak, the ability of the schools to resist risks is still weak, and the supports of resources for its sustainable development is still weak. Perhaps there is no an industry is as sensitive as the private education industry on depending on the relevant educational laws and policies. Therefore, from the points of view of the practitioners and the researchers of the private education, the relevant laws and policies determines the development of the private education whether in a climax or in a trough, and this kind of difference of climax and trough is compared as the repeated temperature variation of "spring” and "winter".

\section{The Phylogeny of Laws and Policies of Private Higher Education}

Reviewing the phylogeny of the policies and laws of private education in China, it has gone through four stages: origin and start (1982-1992), promotion and development (1992-2002), standardization and system (2002-2010), adjustment and deepening(2010-now). Every change of educational policies and laws has a significant impact on the survival, development and growth of private education; the publication of each policy and law is not only the reflection of the practical experiences and innovations in private education and the response to the problems and puzzles in the process of practice, but also the result of the balance between the innovations and practices of the private education and the old regulations and policies.

In this stage, from the perspective of the constitution, the government made a unified stipulation on running schools by social forces for the first time, which laid a basic legal foundation for running private schools. In 1987, the Interim Regulations on Running Private School was put into force; it is the first comprehensive official documents on running private schools after the implementation of the Reform and Open Up policy in China, from that time on, private higher education in China has entered the era of running private school according to regulations and laws. By the encouragement and guidance of this regulation, the scale of private higher education in China has expanded rapidly, and the first developmental climax of private higher education in China was coming. By 1991, the total number of private colleges and universities had reached $450^{[1]}$.

In 1993, the government first put forward that: "the state adopts the policy of actively 
encouraging and supporting, correctly guiding, and strengthening the management on running schools by social organizations and individual citizens" in 1993: Strategies and Guidelines for Education Reform in China. In the some year, the Interim Regulations on Running Private College and University was published and put into force; it definitely stipulated that "Private colleges and universities are the integral part of the cause of higher education in China." Under the guidance of the "16-character" policy, running schools by non-governmental sectors had rapidly developed again, and the private higher education had made progress rapidly, which was reflected on the two major breakthroughs: first, the number of private institutions of higher education in China had exceeded 1000 in 1995, the total number had increased from 450 in 1991 to 1209 in 1995; second, in 1996, the students were enrolled of the private colleges and universities in China had reached 1 million $^{[2]}$. In 1997, the Sate Council had published the first administrative regulation----Regulations on running schools by non-governmental sectors, which confirmed the legal status of the private education, indicated a new stage that running, managing and administering private schools according to law was coming. However, the Regulation also stipulated that ----" the government strictly controls the social force to hold higher education institutions "----which had a certain inhibitory effect on the rapid development of the private higher education, but at the same time, it also corrected and restrained many nonstandard acts and profit-making behaviors in the process of the rapid development of the private higher education since the 1990s.

In this stage, the first special low of private education----Private Education Promotion Law (2002), and its supporting regulation---- Enforcement Regulation of Private Education Promotion Law (2004) were published and put into force, this indicated the private education has entered the legalization stage, and promoted the standard and regular operation of the private education. Since then, the government had issued a series of policy documents that aimed at the healthy development of the private colleges and universities, such as Notice on Strengthening the Standard Management and Guiding the Healthy Development of Private Colleges and Universities (2006), Regulations on the Administration of Running Private Colleges and Universities (2007), Measures for the Establishment and Management of Independent Colleges (2008), etc. These documents had promoted the formation of the policy system of private higher education preliminarily, and had increased the new vitality of the private higher education. However, because there were still no clear regulations on the value evaluation of the schools, on the attribute of juridical person, on the ownership of schools' property right, on the autonomy of running a school, and on the official support policy, etc, and it failed to arouse the enthusiasm of non-governmental investment in education, so there were also a lot of problems that blocked the healthy development of the private education.

In 2010, the National Outline of Medium and Long Education Reform and Development (2010-2020) was put into force, it clarified that "private education is an important factor that promotes the development of education and the important force to promote education reform", and the government would adopt the policy of "developing the public higher education and private higher education together" as an important task for the development of higher education in this stage. In the late of 2016, the Private Education Promotion Law was revised by the National People's Congress, and the General Office of the CPC Central Committee and the relevant Ministries and Commissions of the State Council also issued 4 supporting documents one after another. From that time on, the regulations and policies of " $1+4$ ", which was composed of the new revised Private Education Promotion Law and the four supporting documents, constitute the basic policy system of the private education of China in the new century.

\section{Classified Management is the Historical Inevitability of the Development of the Private Higher Education}

Private colleges and universities can choose their own position----non-profit organization or profit-making organization, and the government carries out the classified management system for private schools----which are undoubtedly the most important piont and the biggest breakthrough of the new revised Private Education Promotion Law. This new law clarifies the vague tendency of 
non-profit and profit-making that exists in the practices of running private education, and it responds to the subjective wishes of the donors. At the some time, it assimilates the academic research results of classified management and the appeals of the academic circles for carrying out the classified management in recent years, and it reflects the mainstream value orientation of the CPC and the government for the development of private education. For the government, the new revised law actively encourages and supports social forces to organize non-profit private schools. On this basis, the government can establish a differential policy system which gives priorities to the non-profit private schools. This decision of establishing the differential policy system will undoubtedly greatly strengthen the confidence of the investors of the non-profit private schools, it will further safeguard the legitimate rights and interests of teachers and students of non-profit private colleges and universities, and it will further promote the non-profit schools to develop healthily and to strive for becoming excellence and first-class in the world.

The history of the development of private higher education in China is a history of contradiction between encouragement and restriction; it is also a complex educational developmental history of cultural ideals and commercial interests, which goes through the whole history of running private schools. The foundation and premise of the restoration and development of the private higher education in China are the political background of reform and opening up, the commercial opportunity of the scarcity of the public higher education and the demand of the era----"running great education in poor countries". From the perspective of the status of the investors of the private schools, there are retired old teachers, old cadres and young and middle-aged intellectuals who have bravely devoted themselves to business, as well as the private entrepreneurs, enterprises and social institutions, and non-governmental organizations. From the perspective of the initial motivation of the investors, there are not only the investors who want to realize the self-value of promoting the development of the country vigorously by means of education, but also investors who have a cute view of the huge business opportunities contained in the serious shortage of public higher education and want to earn more commercial profits by running private schools. From the perspective of capital investment, there are not only non-profit investments, but also profit-making investments, and the mixed investments of the two kinds. Therefore, the non-profit investments and the profit-making investments are always coexisting, which can be called "two rivers flow independently " and "two peaks stand facing each other." Especially when the independent colleges, which are established jointly by the public colleges and universities and the private capital, join in the private education, the character of profit-making of the private higher education industry becomes more serious.

It is precisely because of the different founders, different motivations and different kinds of capital investment that there are lots of differences in running private schools, such as the different positions, different objectives, different planning, different models, different operation mechanisms, and different teaching qualities, etc. If we do not carry out the classified position and the classified management, and continue developing private higher education without using differential policies between the non-profit schools and profit-making schools, it will not beneficial for the government to carry out the differential supporting policies, and will not beneficial for the sustainable and healthy development of the private education industry as well; what's more, it is not only conducive to the realization of the ultimate functions of private colleges and universities, but also deviates from the ultimate value and objective of education cause. Therefore, at present, the government clearly classifies the private schools into non-profit schools and profit-making schools, and distinguishes the differences between cultural organizations and the commercial organizations; these measures all have strong realistic pertinence.

\section{The Practical Significances of Classified Management}

Non-profit private colleges and universities are fundamentally different from the profit-making private colleges and universities in the aspects of value orientation and purpose of running schools. As the non-profit voluntary organizations, the non-profit private colleges and universities are the social education organizations which engage in organizing the public welfare activities of education 
and servicing the public, and which are established by the private capital. In the aspect of finance, it is non-profit, it has no financial objective, and it can not use the surplus that is out of the schools. At the some time, the investors of the schools do not have the ownership of the schools even though they invest the schools a lot, and the residual assets after settlement must be used to the non-profit educational activities. In the aspect of investment, the colleges and universities not only receive the subsidies of their clients, but also receive the donation from the government and the society. The establishment and implementation of the classified management system after the new revised law was put into force are the continuation and change of the restrictive policy ----"prohibiting for profit" in the past. Its practical significances are as follows:

(1) To adopt the classified management to the non-profit and profit-making colleges and universities is not only the distinctive differentiation of the two kinds of schools, but also the most strong protection of them in aspect of legislation; it is helpful for the healthy development of the two kinds of school. The new revised law establishes the developmental mechanism of private schools----“same but differential”, it allows the investor to choose running a non-profit school or running a profit-making school, so that it fundamentally clarifies and resolves a major problem which has been puzzling private education for a long time, i.e., the nature of private education is non-profit or profit-making, and it embodies the characteristics of the times that is open and inclusive on private education laws and policies.

(2) It distinguishes the standard of classification and clarifies the juridical person attribute of the private school. The new revised law makes it clear that the core of the distinctions between the two types of schools are whether the organizers of private schools can obtain the benefits out of running a school, and whether the balance of the schools can be distributed at the time of termination of the school. In accord with the newly published General Principles of Civil Law, non-profit and profit-making private schools can be registered as non-profit juridical persons and profit-making juridical persons respectively, which establishes the legal basis of juridical person attribute for the double-track operation of private schools ${ }^{[3]}$.

(3) It affirms and protects the value orientation of public welfare that non-profit private colleges and universities fully serve the national interests and public interests, and highlights the legitimacy of non-profit private colleges and universities. It is helpful for the government to increase supports on carrying out the differential support policy and promoting the fast development of non-profit private colleges and universities.

(4) It adheres to the guidance of public welfare, and strengthens the socialist direction of running private schools. In the new revised law, the relevant clauses about the Party building in the private schools are added, which is an important institutional arrangement to ensure the running direction of the private schools and to maintain the nature of public welfare of the schools.

\section{Acknowledgements}

Pro: Scientific Research Program Funded by Shaanxi Provincial Education Department (Program No. 15JZ055)

\section{References}

[1] Education, Science, Culture and Public Health Committee of the National People's Congress of the People's Republic of China. Research on Private Education and Exploration on the Legislation[M]. Guangzhou: Guangdong Higher Education Press, 2001.

[2] Zhou Haitao, etc. Research on the Policies of Classified Management of Private Schools[M]. Beijing: Economic Science Press, 2016.

[3] Zhou Haitao. Private Education Will Achieve Multiple Positive Effects----Focusing on the New Private Education Promotion Law[J]. Journal of The Chinese Society of Education, 2017(3). 